\title{
KASVATUS\&AIKA
}

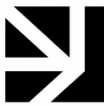

VERTAISARVIOITU

ArtikKeli

https://doi.org/10.33350/ka.82723

\section{Inhimillisen ja ei-inhimillisen suhde luokanopettajakoulutuksen opetussuunnitelmissa}

\author{
Auli Toikkanen \& Tiina Nikkola
}

Tässä artikkelissa tarkastelemme posthumanistisesta näkökulmasta inhimillisen ja ei-inhimillisen suhteen rakentumista luokanopettajakoulutusten opetussuunnitelmissa. ${ }^{l}$ Inhimillisen ja ei-inhimillisen suhdetta koskevat kysymykset ovat erityisen ajankohtaisia ympäristökriisien ja ilmastonmuutoksen aikakaudella. Tutkimusaineistona käytettiin suomalaisten luokanopettajakoulutusten opetussuunnitelmia, jotka kerättiin opettajankoulutuslaitosten verkkosivuilta loppuvuonna 2017 ja alkuvuonna 2018. Aineisto analysoitiin laadullisen sisällönanalyysin keinoin sekä toimijaverkkoteorian verkostomaista todellisuuskäsitystä että puhdistamisen ja kääntämisen käsitteitä hyödyntäen. Puhdistamisella tarkoitetaan toimijaverkkoteoriassa pääasiassa inhimillisen erottamista ei-inhimillisestä ja kääntämisellä inhimillisten ja eiinhimillisten välisten verkostojen syntymistä. Tutkimuksen tuloksena havaittiin, että inhimillisen ja ei-inhimillisen suhde rakentuu opetussuunnitelmissa joko ei-inhimillisen merkityksen häivyttämisen tai sen tunnustamisen kautta. Opetussuunnitelmissa ihminen näyttäytyy pääosin aktiivisena toimijana eiinhimillisen toimittaessa resurssin virkaa. Ei-inhimillisiin luonnonresursseihin ja teknologiaan kohdistuu odotuksia suhteessa inhimilliseen oppimiseen ja kehitykseen. Koulutuksessa on mahdollisuus tutkia ja kyseenalaistaa inhimillisen ja ei-inhimillisen suhdetta ja niitä koskevia lähtöoletuksia. Myös välttämättömyys muuttaa elämäntapaamme nykyistä kestävämpään suuntaan on vahvana perusteena argumentoitaessa posthumanistisen ajattelun tarpeellisuudesta opettajankoulutuksessa.

1 Artikkeli perustuu Auli Toikkasen maisterintutkielmaan (2019). 


\section{Johdanto}

Ihminen on osa luontoa ja täysin riippuvainen ekosysteemien elinvoimaisuudesta. Tämän ymmärtäminen on keskeistä ihmisenä kasvussa. Perusopetuksessa tunnistetaan kestävän kehityksen ja ekososiaalisen sivistyksen välttämättömyys, toimitaan sen mukaisesti ja ohjataan oppilaita kestävän elämäntavan omaksumiseen. (POPS 2014, 16.)

Ekososiaalinen sivistys on osa nykyisen perusopetuksen opetussuunnitelman arvopohjaa. Perusopetuksen opetussuunnitelman kuvauksen mukaan inhimillinen kasvu on tiiviisti sidoksissa ei-inhimilliseen. Tässä tutkimuksessa tarkoitamme inhimillisellä ihmistä ja ihmiseen liittyviä prosesseja, ja ei-inhimillisellä taas lähtökohtaisesti kaikkea muuta kuin ihmistä, esimerkiksi ympäristöä, eläimiä ja teknologiaa. Tuotanto- ja kulutuskeskeisyys sekä siihen liittyvä välineellinen suhtautuminen ei-inhimilliseen luontoon ovat tabuja, joille nykyinen käsityksemme hyvinvoinnista perustuu (Salonen \& Bardy 2015, 5). Jatkuvasti kasvavan tuotannon ja kulutuksen myötä syntyy kuitenkin myös uhkia ihmisen hyvinvoinnille ja luonnon monimuotoisuudelle.

Ekososiaalinen sivistys tarkoittaa sellaista sivistyneisyyttä, jossa ymmärretään materiaalisten resurssien rajallisuus, ja jossa kasvatetaan materiaalisen sijaan aineetonta ja henkistä pääomaa (Salonen \& Bardy 2015, 12). Se on ymmärrystä ihmisyksilöstä luonnosta ja muista ihmisistä riippuvaisena olentona. Ekososiaalisen sivistyksen arvopohja koostuu vastuullisuudesta, kohtuullisuudesta ja ihmistenvälisyydestä. Vastuullisuus tarkoittaa kykyä ymmärtää muiden asemaa, myötätuntoa muita kohtaan, vastuunottamista toisista sekä elämän edellytysten mahdollistamista seuraaville sukupolville. Kohtuullisuudessa on kyse sen ymmärtämisestä, mikä määrä aineellista hyvinvointia ihmiselle riittää sekä tärkeiden tarpeiden erottamisesta haluista. Ihmistenvälisyydellä viitataan yhteisöön kuulumiseen ja osallisuuteen. (Salonen \& Bardy 2015, 8-10.)

Ihminen on kuitenkin peruuttamattomasti muuttanut maapallon ja sen elämän edellytysten tilaa. Ympäristökriiseissä ei ole kyse ongelmista, jotka ratkaistuamme voimme palata niitä edeltäneeseen aikaan. Sen sijaan ne uhkaavat maapallon ekosysteemejä sekä yhteiskuntaa ja kulttuuria. (Toivanen \& Pelttari 2017.) Toimivat ekosysteemit ovat hyvän elämän ehdoton edellytys. Pelkästään teknologisesta kehityksestä ei ole apua resurssien niukkenemisen ongelmaan. Ekosysteemien vaarantuminen vaarantaa kaikenlaisen, myös teknologisen, kehityksen. (Salonen \& Bardy 2015, 6.) Tämän vuoksi koulutuksessa on ajankohtaista ja jopa välttämätöntä teknologian mahdollisuuksien käsittelemisen ohella huomioida myös sen tarjoamien mahdollisuuksien rajat.

Veli-Matti Värri $(2018,12)$ painottaa, että ihmisen ja ei-inhimillisen suhteen uudelleenarviointi on välttämätöntä elämän turvaamiseksi. On perusteltua kysyä, toteutuvatko uudelleenarviointi sekä esimerkiksi ekososiaalisen sivistyksen painottamat osa-alueet opettajankoulutuksessa riittävästi. Feministisen uusmaterialismin piirissä esimerkiksi Donna Haraway (2008) on nostanut esiin haasteita, joita inhimillisen ja ei-inhimillisen kohtaamisiin sekä ihmisen ei-ihmisistä tekemiin määritelmiin liittyy. Ihminen ei ole maailmassa ulkopuolinen tarkkailija vaan osa maailmaa, ja siten ihmisyys kehkeytyy jatkuvasti "yhteismuotoutumisessa" (Barad 2008, 146). Pohjana suhteen uudelle määrittelylle voisi olla kahtiajakojen hylkääminen erityisesti ajattelemalla ihmisyyden prosessi osaksi muita ilmiöitä.

Posthumanismissa ihmiskeskeisyyttä sekä inhimillisen ja ei-inhimillisen lähtökohtaista erottelua lähestytään kriittisesti. Posthumanismissa tarkastellaan ihmistä ja elämän eri osaalueita näkökulmasta, joka ottaa huomioon ihmisen kehityksen erilaisten ei-inhimillisten, teknologisten ja materiaalisten muotojen rinnalla (Wolfe 2010, xxv). Näihin kysymyksiin 
opettajankoulutuksessa on herätty toistaiseksi lähinnä teoretisoinnin kautta ja käytännön sovelluksia vasta kehitetään. Esimerkiksi Värri $(2014 ; 2018)$ on luonnostellut ekologisesti kestävämpää opettajankoulutusta ja kasvatusta. Tässä artikkelissa tarkastelemme suomalaisen luokanopettajakoulutuksen opetussuunnitelmia posthumanistisesta näkökulmasta. Tarkastelemme erityisesti sitä, miten inhimillisen ja ei-inhimillisen suhde rakentuu aineistossa.

\section{Opetussuunnitelmien avulla kiinni koulutuksen taustaoletuksiin}

Opetussuunnitelma ohjaa koulutuksen nykyistä ja tulevaa toimintaa, mutta samanaikaisesti se perustuu yhteiskunnan ja sivistyksen perinteisiin. Se luonnehtii suuntaviivat koko kouluyhteisön toiminnalle ja kertoo samalla yksilöiden toiminnasta yhteisössä. (Rokka 2011, 42.) Goodson $(2001,20)$ määrittelee opetussuunnitelman julkiseksi perusteluksi opetuksen tarkoituksesta, lähtökohdista ja opetusta koskevista valinnoista. Opetussuunnitelma asiakirjana siis sisältää yhteisesti hyväksyttyjä julkilausumia opetuksen tavoitteista ja arvoista. Se on perusta, jonka pohjalta opetusta rakennetaan. Kirjallinen opetussuunnitelma on Goodsonin $(2001,20)$ sanoin "muuttuvan maaston kartta". Kasvatuksella pyritään tavoitteisiin, jotka johdetaan ideologisista, taloudellisista ja poliittisista arvoista ja ihanteista. Tavoitellun oppimisen ja sivistyksen määrittely on tärkeä osa koulutuksen lähtökohtia. Mikäli kasvatusta perimmäisinä ohjaavat lähtökohdat pysyvät muuttumattomina ja piilossa, on myös ekologisen kestävyyden tavoitteleminen hyvin vaikeaa. (Värri 2018, 21.) Näistä syistä opetussuunnitelma sopii aineistoksi luokanopettajakoulutuksen taustalla olevien lähtöoletusten tutkimiseen.

Käsittelemme opetussuunnitelmia tässä artikkelissa teksteinä, jotka kertovat jotakin inhimillisen ja ei-inhimillisen suhteesta. Opetussuunnitelmat ovat rooliltaan kahtalaisia; ne ovat toisaalta materiaalisia, ihmisen tuottamia dokumentteja eli ei-inhimillisiä objekteja, mutta myös aktiivisia toimijoita opetuksen järjestämisessä. Sen lisäksi että kirjalliset dokumentit ovat kulttuurisia ja diskursiivisia, niiden materiaalinen muoto vaikuttaa siihen, millaisia toimijoita ne ovat inhimillisen ja ei-inhimillisen verkostossa. Oleellista on sekä arvioida kirjallisten dokumenttien toimijuutta ja toimintaa verkostossa että samanaikaisesti nähdä ne verkoston toiminnan seurauksena. (Fenwick \& Edwards 2010, 8.) Valtakunnalliseen perusopetuksen opetussuunnitelmaan verrattuna yliopistokohtaiset opettajankoulutuksen opetussuunnitelmat eivät ole samalla tavalla yhtenäinen ja selkeä kokonaisuus. Niissä on kuitenkin kelpoisuuden antavana koulutuksena paljon yhteneviä piirteitä. Tarkastelemme eri yliopistojen luokanopettajakoulutusten opetussuunnitelmia kokonaisuutena, mitä ei ole aiemmin juurikaan tehty.

Opetussuunnitelmia tutkimalla päästään sen ytimeen, miten inhimillinen ja ei-inhimillinen ovat vuorovaikutuksessa keskenään kasvatuskontekstissa. Nostamalla esiin opetussuunnitelmien ajattelutapojen logiikkaa on mahdollista herättää kysymyksiä myös koulutuksen käytänteisiin liittyen. Oletamme, että opetussuunnitelmat pitävät sisällään niin koulutusten ajattelutapoihin sisäistyneitä kuin käytäntöihinkin vaikuttavia lähtöoletuksia. Tässä tarkastelemme kuitenkin ainoastaan opetussuunnitelmissa rakentuvaa inhimillisen ja ei-inhimillisen suhdetta, ja tutkimuksen ulkopuolelle rajautuu esimerkiksi kysymys siitä, miten inhimillisen ja ei-inhimillisen suhde rakentuu luokanopettajakoulutusten käytännön opetuksessa.

Opetussuunnitelmatutkimus on kasvatustieteellisessä tutkimuksessa oma osa-alueensa, jonka puitteissa tarkastellaan opetussuunnitelmia useista eri näkökulmista (esim. Apple 2010). Vaikka opetussuunnitelmatutkimus on kansainvälisesti vilkas ja viime vuosina myös tutkimusalana lisääntyvän kansallisen kiinnostuksen kohde, ovat inhimilliseen näkökul- 
maan tukeutuvat tavat tarkastella opetussuunnitelmia selkeästi vallitseva tapa (ks. esim. Autio, Hakala \& Kujala 2017). Lähestymistapana posthumanistinen, inhimillisen ja ei-inhimillisen suhteeseen keskittyvä tutkimusnäkökulma on opetussuunnitelmien tutkimisessa toistaiseksi harvinainen, ja etenkään opettajankoulutuksen opetussuunnitelmia ole juurikaan tarkasteltu ei-inhimillisen huomioivasta näkökulmasta. Ei-inhimillinen on läsnä itsestään selvänä ja sanallistamattomana elementtinä opetussuunnitelmatutkimuksessa. Tämä tutkimus paikkaa kuvattua tiedonaukkoa painottamalla ensisijaisesti posthumanistista kysymyksenasettelua ja tulkintaa opettajankoulutusten opetussuunnitelmissa.

\section{Posthumanistinen näkökulma - ihmiskeskeisyydestä kohti verkostomaista ajattelua}

Tässä artikkelissa posthumanismilla tarkoitetaan ajattelusuuntausta, joka kyseenalaistaa ihmiskeskeisyyden sekä inhimillisen ja ei-inhimillisen välisen lähtökohtaisen erottelun. Wolfen (2010, xxv) mukaan posthumanismissa ihmisyyden piirteitä tarkastellaan laajemminkin kuin vain inhimillistä tietoisuutta ja ajattelua korostamalla. Samalla ihminen tullaan asettaneeksi osaksi evoluution historiaa muiden eläinten joukkoon. Lummaan ja Rojolan $(2014,14)$ mukaan posthumanistisessa ajattelussa pyritään luopumaan käsityksestä ihmisestä, joka määrittyy vastakkaisena ei-inhimilliselle.

Kasvatustieteellisessä keskustelussa on tehty yrityksiä laajentaa vallitsevaa yksilökeskeistä ja rationalistista tietokäsitystä. Esimerkiksi kasvatustieteen psykoanalyyttisen lähestymistavan piirissä on nostettu tarkasteluun käsitys rationaalisuuden rajoituksista, kehollinen tieto ja kehityskritiikki. (Esim. Britzman 2003; 2009.) Nämä keskustelut eivät kuitenkaan ole kasvatustieteessä valtavirtaa. Posthumanistisesti ajateltuna ihminen ei ole pysyvä entiteetti, vaan ihmisyys kehkeytyy ja muuttuu jatkuvasti (Barad 2008, 139).

Inhimilliseen toimintaan ja tutkimukseen liittyy myös esteitä ja rajoitteita. Posthumanismia kohtaan onkin esitetty myös kritiikkiä. Post-etuliite posthumanismin käsitteessä viittaa muutokseen ja ajalliseen irtiottoon humanismista, mutta irtioton ajatus juontuu humanistisen ajatteluperinteen käsityksestä ihmisestä kyvykkäänä kontrolloimaan muutosta vapaan tahtonsa avulla (Lummaa \& Rojola 2014, 28). Ihmisen mahdollisuus huomioida ei-inhimillisen merkitystä on lähtökohtaisesti haastavaa rajallisesta ihmisyydestä käsin. Tämänkin tutkimuksen lähtökohtana oleva ajatus ei-inhimillisen esiin nostamisesta on sikäli ongelmallinen, että se edelleen ylläpitää inhimillisen ja ei-inhimillisen kahtiajakoa.

Vaikka posthumanismi käsitetään usein erontekona humanismiin, tutkimisen arvoista on myös se, mikä humanismissa on posthumanismia. Silloin kiinnostuksen kohteena ovat esimerkiksi ne piirteet humanismissa, jotka purkavat erottelua inhimillisen ja ei-inhimillisen välillä. (Lummaa \& Rojola 2014, 28-29.) Haraway (2008, 176-177) puolestaan haastaa etsimään ihmisiä ja ei-ihmisiä yhdistäviä ehtoja. Posthumanistista ajattelua luokanopettajakoulutukseen saataisiin tutkimalla ihmisen rajallisuutta, ihmisen ja muun luonnon samankaltaisuutta sekä ei-inhimillisen merkitystä osana inhimillistä oppimista.

Posthumanismi on lähellä uusmaterialistista ajattelua. Niiden välille ei ole tehty yksiselitteistä erottelua, joskin posthumanismia pidetään moniäänisempänä ajattelutapana, kun taas uusmaterialismin piiristä on selkeästi nimettävissä siihen oleellisimmin vaikuttaneet ajattelijat (Lummaa \& Rojola 2014, 23). Posthumanistinen ja uusmaterialistinen ajattelu lähtökohtana luokanopettajakoulutusten lähtöoletusten ja opetussuunnitelmadokumenttien voi ajatella rakentuvan paitsi kielellisesti ja sosiaalisesti, myös materiaalisesti. Lehtosen $(2008,29)$ mukaan materiaalisuuden uusi tuleminen on tutkimuksessa tarkoittanut esimerkiksi kiinnostusta ei-inhimillisiin kanssaeläjiimme, joiden läsnäoloon arkiympäristöjemme rakentuminen kytkeytyy. 
Materiaalisuuden uusi nousu on myös herättänyt kysymyksiä siitä, miten ei-inhimilliset tekijät vaikuttavat inhimilliseen pystyvyyteen (Lehtonen 2008, 27). Valkosen, Lehtosen ja Pyyhtisen $(2013,218)$ mukaan materiaalisuudesta kiinnostuneessa yhteiskuntatutkimuksessa on mahdollista tavoittaa ajatus yhteiskunnallisesta elämästä moniaineksisena ja erilaisista osasista koostuvana. Ei-inhimillisiä ei oleteta passiivisiksi ihmisen toiminnan kohteiksi vaan myös keskeisiksi toimijoiksi yhteiskunnassa. Ei-inhimillisiä ei kuitenkaan tarkastella niiden olemuksen tai ominaisuuksien vuoksi vaan niiden yhteyksien kautta, joissa ne tulevat osaksi jaettua todellisuutta. (Valkonen ym. 2013, 218-219.) Kansainvälistä posthumanistista keskustelua on avattu esimerkiksi feministisen (uus)materialismin piirissä. Esimerkiksi Barad (2008, 135) kuvaa todellisuutta, jossa olemassaolon ja toimijuuden lähtökohta ei ole yksilö vaan sen jatkuva muotoutuminen yhdessä muiden yksiköiden kanssa. Nämä yksiköt ovat sekä inhimillisiä että ei-inhimillisiä.

Myös toimijaverkkoteoria tulee varsin lähelle posthumanistista ajattelutapaa. Toimijaverkkoteoriassa inhimillistä toimintaa määrittävien verkostojen hahmotetaan ulottuvan huomattavasti kielellistä ja sosiaalista ihmisyhteisöä laajemmalle. Sekä posthumanistisen että toimijaverkkoteoreettisen kritiikin kohteena on usein ollut ei-inhimillisestä erotettu ihmissubjekti. Toimijaverkkoteorian yhtenä kehittäjänä tunnettu Bruno Latour ei kuitenkaan ole mieltänyt itseään posthumanistiksi (ks. Lummaa 2014, 266). Posthumanismin kyseenalaistaessa inhimillisen ja ei-inhimillisen erotteluja myös toimijaverkkoteoriassa kahtiajakoihin suhtaudutaan pysyvien lähtökohtien sijaan verkostojen toiminnan seurauksina (ks. Fenwick \& Edwards 2010, 3).

Latour $(1993,10)$ esittää, että sana “moderni” on kytköksissä kahteen erilaiseen proses siin: kääntämiseen ja puhdistamiseen. Ensimmäisessä prosessissa, kääntämisessä, luodaan inhimillisen ja ei-inhimillisen yhdistelmiä, hybridejä. Toisessa prosessissa, puhdistamisessa, puolestaan määritellään inhimilliselle ja ei-inhimilliselle omat, sekoittumattomat alueet. Kääntämisen prosessissa syntyy verkostoja, ja puhdistamisen prosessi puolestaan vastaa olemukseltaan modernia kriittistä asennetta, joka erottaa toisistaan luonnon ja kulttuurin. Kääntämisen ja puhdistamisen prosessit ovat riippuvaisia toistensa olemassaolosta, ja ilman toinen toistaan niiden tekemä työ olisi tarpeetonta. Kääntämistä ja puhdistamista tulisikin tarkastella rinnakkain niitä erillisiksi prosesseiksi jakamatta. (Latour 1993, 10-11.)

Puhdistamisen ja kääntämisen prosessien kautta voi pyrkiä ymmärtämään inhimillisen ja ei-inhimillisen erottelua tai toisaalta niiden välisten verkostomaisten suhteiden rakentumista. Puhdistamisen prosessi rakentuu vakiinnuttamalla normeja ja säännönmukaisuuksia, minkä vuoksi asioita voidaan luokitella ja niille voidaan antaa painoarvoa eri tavoin (ks. Fenwick \& Edwards 2010, 49). Kasvatuksen kontekstissa puhdistamisen prosessin kautta määritellään esimerkiksi oppiminen sekä toivottu oppimistulos ja ei-toivottu oppimistulos. Kääntämisen prosessin seurausta ovat verkostot, joissa ei-inhimillinen teknologia tai luonto ja inhimilliset prosessit sekoittuvat. Esimerkki tällaisesta verkostosta on luonnontieteen oppitunti, jonka aikana oppilaat ja ei-inhimillinen teknologia työskentelevät yhdessä ei-inhimillisen luonnon ilmiöiden mittaamisessa ja havaintojen tallentamisessa. Latourin (1993, 11) mukaan esimerkki kääntämisen prosessin vaikutuksesta on verkosto, jossa yhdistyvät esimerkiksi tutkija tunteineen, tieteen ja teollisuuden toiminta sekä ilmakehän kemia. Tässä tutkimuksessa analysoimme kääntämisen ja puhdistamisen käsitteiden kautta sitä tapaa, jolla inhimillisen ja ei-inhimillisen suhde luokanopettajakoulutuksen opetussuunnitelmissa rakentuu. 


\section{Aineisto ja analyysi}

Tutkimuksen empiirinen aineisto on kerätty loppuvuonna 2017 ja alkuvuonna 2018, ja siihen kuuluvat kaikki koontihetkellä verkossa saatavilla olleet suomalaisten luokanopettajakoulutusten opetussuunnitelmat. Opetussuunnitelmat ovat julkisia asiakirjoja, jotka ovat vapaasti jokaisen luettavissa ja tutkimuksen hyödynnettävissä. Tutkittavat koulutukset ovat Helsingin, Itä-Suomen, Jyväskylän, Lapin, Oulun ja Turun yliopistojen luokanopettajakoulutukset sekä Jyväskylän yliopiston Kokkolan yliopistokeskus Chydeniuksen luokanopettajien aikuiskoulutus ja Snellman-korkeakoulun luokanopettajakoulutus. Aineisto koostuu siis kahdeksan luokanopettajakoulutuksen opetussuunnitelmista ja sen kokonaispituus on 46 sivua (8494 sanaa). Aineiston ulkopuolelle on rajattu koulutusta kuvaavia, mutta tutkimustehtävän kannalta epäolennaisia osioita, kuten tutkinnon suorittamisaikatauluja sekä yksittäisten opintojaksojen kuvauksia ja luetteloita tutkinnon osana suoritettavista kursseista.

Luokanopettajakoulutusten opetussuunnitelmien kieltä luonnehtii muodollisuus, ja ensituntumalta ne vaikuttavat melko samanlaisilta sisällöltään, sanastoltaan ja rakenteeltaan. Opetussuunnitelmien kieli sisältää yleisiä ilmaisuja, tavoitteita ja ihanteita. Esimerkiksi kestävä kehitys, teknologia, oppimisympäristö ja inkluusio ovat käsitteitä, jotka vaikuttavat liittyvän opettajan ammatin, kasvatuksen ja koulun peruskysymysten lisäksi myös sellaisiin kysymyksiin, joita ajankohtaiset yhteiskunnalliset muutokset herättävät. Opetussuunnitelmia kuvaa suurelta osin pyrkimys tuoda esiin monenlaisia näkökulmia laittamatta niitä kuitenkaan yleensä arvojärjestykseen. Tällainen lähestymistapa jättää avoimeksi sen, miten koulutus toteutetaan käytännössä. Sen perusteella luokanopettajakoulutusta on mahdollista toteuttaa yksittäisessäkin opettajankoulutuslaitoksessa monella eri tavalla.

Opetussuunnitelmilla on kuitenkin vaikutusta niihin lähtöoletuksiin, joita luokanopettajakoulutuksessa muodostuu. Tässä artikkelissa kysymme, millä tavoin inhimillisen ja ei-inhimillisen suhde luokanopettajakoulutuksen opetussuunnitelmissa hahmotetaan.

Tutkimuskysymykset ovat:

1. Miten inhimillisen ja ei-inhimillisen suhde rakentuu luokanopettajakoulutusten opetussuunnitelmissa?

2. Miten kääntämisen ja puhdistamisen prosessit vaikuttavat suhteen rakentumiseen?

Aineistoa tulkitaan posthumanismista kumpuavasta teoreettisesta viitekehyksestä käsin. Analyysi on teoriaohjaavaa (Tuomi \& Sarajärvi 2018, 109-110), ja sen lähtökohta on ajatus inhimillisten ja ei-inhimillisten prosessien yhteenkietoutuneesta rinnakkaiselosta. Siksi kiinnostuksen kohteena tässä tutkimuksessa on erityisesti se, miten opetussuunnitelma-aineistossa viitataan inhimillisen ja ei-inhimillisen välisiin erontekoihin sekä toisaalta niiden yhdistelmiin. Lähestymme tätä erityisesti kääntämisen ja puhdistamisen prosessien kautta. Valitsemastamme näkökulmasta opetussuunnitelmat erosivat toisistaan siten, että jotkut opetussuunnitelmat näyttäytyivät verkostomaisempina kun taas toisissa pitäydyttiin luettelemaan opettajan ammatissa tarvittavia taitoja. Opetussuunnitelmat muodostuivat siis rakenteeltaan keskenään eri tavoin. Keskitymme analyysissa opetussuunnitelmiin, joissa tavoiteltua asiantuntijuutta selitettiin auki verkostomaisesti ja suhteessa ei-inhimillisiin elementteihin.

Mainintoja ei-inhimillisistä on opetussuunnitelmissa ylipäätään hämmästyttävän vähän, minkä vuoksi posthumanistisen näkökulman soveltaminen aineiston analyysissa tuntui aluksi kankealta ja jopa mahdottomalta. Opetussuunnitelma-aineistossa ei mainita lainkaan 
eläimiä, luonnon käsitettä käytetään ei-inhimillisen luonnon merkityksessä ainoastaan kahden luokanopettajakoulutuksen opetussuunnitelmassa ja ei-inhimillinen ympäristökin mainitaan vain harvoin, vaikka eläimet ja muut luontokappaleet ovat osa yhteiskuntamme arkipäivää monin tavoin. Mainintoja teknologiasta on aineistossa useampia, ja niistä suurin osa koskee tieto- ja viestintäteknologiaa. Opetussuunnitelmien ja posthumanistisen ajattelun välinen kitka oli oleellinen havainto, joka paljastaa, miten vaikeaa ihmisen on ajatella ja tehdä tutkimusta posthumanistisesta näkökulmasta. Tämän havainnon pohjalta alkoi kuitenkin hahmottua ei-inhimillisen rooli opetussuunnitelmissa.

Alustavan analyysin perusteella havainnot ryhmiteltiin kolmeen suurempaan luokkaan: ihmisyyden ja toimijuuden, ei-inhimillisen ympäristön sekä uudistamisen ja kriittisyyden käsittelyyn opetussuunnitelmissa. Seuraavaksi tarkasteltiin luonnon ja kulttuurin sekä inhimillisen ja ei-inhimillisen erotteluja sekä niiden suhteiden rakentumista. Eniten havaintoja löytyi Snellman-korkeakoulun, Itä-Suomen yliopiston, Lapin yliopiston ja Jyväskylän yliopiston luokanopettajakoulutuksen opetussuunnitelmista. Ensin mainituissa kolmessa opetussuunnitelmassa oli läsnä inhimillisestä olemassaolosta erillisen ei-inhimillisen olemassaolon sanallistaminen muita opetussuunnitelmia voimakkaammin.

Lopulta analyysia ohjaavaksi kysymykseksi muotoutui inhimillisen ja ei-inhimillisen välisen suhteen rakentuminen, erityisesti se, miten ja millaisten tekijöiden kautta niiden suhde opetussuunnitelmissa rakentui. Kun aineisto luettiin kääntämisen ja puhdistamisen prosessien kautta, subjektin ja objektin roolit eivät enää näyttäytyneet itsestäänselvinä. Analyysin loppuvaiheessa mukaan aineistoa jäsentämään otettiin häivyttävä ja tunnustava suhde inhimillisen ja ei-inhimillisen välillä.

\section{Häivyttävän suhteen moderni, kriittinen ja kehollinen ihminen}

Häivyttävässä suhteessa ihminen näyttäytyy aktiivisena, kykenevänä ja kriittisenä, ei-inhimillinen puolestaan ihmisen toiminnan kohteena. Latourin $(2006,211)$ mukaan modernin ihmisen mahtavuus perustuu hybridien ja verkostojen rakentamiselle, mutta tällä on kuitenkin käsitys itsestään luonnosta ja muista yhteisöistä erillisenä. Modernin käsite ja määritelmä syntyvät menneisyydelle, "ei-modernille" vastakkaisena (Latour 1993, 10). Esimerkiksi Jyväskylän yliopiston opettajankoulutuslaitoksen opetussuunnitelmassa kriittinen asenne nostetaan nykykoulutuksen tavoitteeksi, ja sitä verrataan opettajankoulutuksen alkujuuriin, jolloin koulutuksessa ja kasvatuksessa merkittävänä nähtiin käytännöllisten kansalaistaitojen opettaminen. Moderni koulutus tavoitteineen on opetussuunnitelma-aineistossa monilta osin kytköksissä kriittiseen asenteeseen. Modernissa ja kriittisessä inhimillisessä tiivistyvät ihmisyyden arvostamisen lisäksi myös ihmisen eettiset velvollisuudet maailmassa.

Opetussuunnitelmissa luokanopettajakoulutus, oppiminen ja ihmisen elämä piirtyvät usein esiin projektina kielellisessä ja sosiaalisessa maailmassa. Oppimisympäristöjen ja oppimiseen vaikuttavien tekijöiden luonne kuvataan yleensä sosiaalisen tai inhimillisen näkökulman kautta.

Oma asiantuntijana olemisen tapa kehittyy tulemalla tietoiseksi omista arvoista, asenteista, tunteista, kiinnostuksen kohteista ja toimintaa ohjaavista periaatteista. Lisäksi tullaan tietoiseksi siitä, että kasvatusalan asiantuntijuus ei kehity tyhjiössä, vaan se rakentuu sosiaalisesti, ja ammatillista toimintaa määrittävät erilaiset reunaehdot, kuten lait, asetukset ja opetussuunnitelmat. (Jyväskylän yliopisto.) 
Opetussuunnitelmien kuvaaman maailman tulkitsemme seuraukseksi prosessista, jossa eiinhimillisen vaikutus puhdistetaan ihmiselämästä, ja jossa inhimillinen oppimisen ja kehittymisen alue erotetaan ei-inhimillisestä alueesta. Tällöin koulutuksen todellisuutta näyttävät määrittävän ensisijaisesti sosiaalisen ja yhteiskunnallisen todellisuuden reunaehdot.

Modernin, kriittisen asenteen avulla pyritään kehittämään asiantuntijuutta ja huomioimaan erilaisia näkökulmia, esimerkiksi kestävän kehityksen mukaista toimintaa opettajan työssä. Moderni, kriittinen asenne on myös kytkeytynyt ihmiselle kuuluviin eettisiin velvollisuuksiin. Luokanopettajakoulutuksen tavoitteena on kouluttaa opettajia, joiden on mahdollista yksin ja yhdessä kyseenalaistaa asioita, kantaa vastuuta sekä rakentaa kasvatuskulttuuria.

\begin{abstract}
Professionaalisen opettajan tulee kyetä koulun muuttuvassa toimintaympäristössä kantamaan eettistä vastuuta paitsi oppilaistaan ja luokastaan, myös koulun, oman ammattinsa ja yhteiskunnan kehittämisestä kestävä kehitys huomioiden. Jatkuvia haasteita opetuksen ja kasvatuksen kentällä ovat kaikkien oppijoiden osallisuuden lisääminen oppimisessa, oppimisympäristöissä ja toimintatavoissa. Tästä syystä opettajien on totuttava arvioimaan ja tarvittaessa myös uudistamaan käsityksiään yhteiskunnasta, koulutuksesta ja pedagogiikasta. (Kokkolan yliopistokeskus Chydenius.)
\end{abstract}

Samalla kun moderni, kriittinen asenne voi haastaa ja muuttaa nykyisiä ajattelutapoja inhimillisen ja ei-inhimillisen suhteesta, se kuitenkin pitää yllä kahtiajakoja, kuten käsitystä aktiivisesta ihmisestä ja passiivisesta ei-inhimillisestä. Luonto ei kuitenkaan esimerkiksi Harawayn (2008, 158-159) mukaan ole ainoastaan ihmisestä erillinen paikka, aarreaitta, suojelun kohde tai hoivaaja. Juuri näitä tavanomaisia stereotypioita tulisi tunnistaa ja kyseenalaistaa suhteen uudelleenmäärittelyssä. Posthumanistisen ajattelun mukaan ihminen ei ole älyltään, psyykeltään, fysiikaltaan tai sosiaalisilta ominaisuuksiltaan vertaansa vailla suhteessa muihin organismeihin, kuten ei-inhimillisiin eläimiin tai koneisiin (Lummaa \& Rojola 2014, 14). Posthumanistinen lähtökohta haastaakin voimakkaasti esimerkiksi eettisten taitojen opiskelua opettajankoulutuksessa. Moderniin, kriittiseen ajatteluun liittyvä eettisten ja yhteiskunnallisten kysymysten pohdinta voi kuitenkin edesauttaa vastuun ottamista ja huolenpitoa ei-inhimillisestä. Sitä kautta se voi myös sitouttaa kestävämmän tulevaisuuden tavoittelemiseen.

Opiskelija tunnistaa ja osaa nimetä niitä yhteiskunnallisia tekijöitä, prosesseja ja rakenteita, joista koulun ja oppilaiden toimintaympäristö rakentuu. Hän osaa kuvata ja jäsentää koulua inklusiivisena, monitoimijaisena ja monikulttuurisena yhteisönä. Opiskelija tunnistaa ammatillisen ja kasvatuksellisen roolinsa yhteiskunnallisena toimijana ja kestävän tulevaisuuden rakentajana. (Itä-Suomen yliopisto.)

Ihminen on luokanopettajakoulutusten opetussuunnitelmien perusteella vastuussa kestävästä tulevaisuudesta. Koulutus tähtää sellaisten taitojen kehittämiseen, joiden avulla tähän vastuuseen voidaan kasvaa. Näiden taitojen kehittyminen on inhimillisen ja ei-inhimillisen suhteen tasa-arvoisemmaksi muuttumisen edellytys, mutta ei sen tae.

Opetussuunnitelmissa esiintyvä ihmisten välisiin suhteisiin keskittyvä kriittisyys asettuu posthumanismin näkökulmasta kyseenalaiseksi. Posthumanistinen kriittisyys pyrkii lisäämään tietoisuutta erilaisista ja moninaisista todellisuuden aineksista, eikä huomio ole ainoastaan ihmisten välisissä valtasuhteissa tai erilaisten ihmisten näkökulmien huomioimisessa (Tammi \& Hohti 2017, 80). Yhteistä näille kriittisyyden ulottuvuuksille voisi kuiten- 
kin olla ihmettelyyn asettautuminen ennalta tietämättömien ilmiöiden edessä (ks. Tammi \& Hohti 2017, 80). Luokanopettajakoulutuksessa tällainen asennoituminen on mahdollinen esimerkiksi lähestymistavassa, jossa astutaan rationaalisen tiedon alueelta kehollisen tiedon alueelle. Jyväskylän yliopiston luokanopettajakoulutus ankkuroituu kuuteen ydinosaamisalueeseen. Näistä esteettinen ydinosaamisalue painottuu kehollisuuteen, kokemuksellisuuteen ja aistimiseen: olemisen tapoihin, jotka tuovat ihmistä lähemmäksi ei-inhimillistä paremmin kuin kriittinen ajattelu.

Opiskelija ymmärtää ihmisen kehollisena olentona, jolla on mahdollisuus kokonaisvaltaiseen moniaistiseen ympäristön kokemiseen. Hän pystyy luomaan välitöntä ja ennalta määrittelemätöntä aistimista merkitsevän esteettisen todellisuussuhteen ympäröivään maailmaan. (Jyväskylän yliopisto.)

Lähtökohtaisten kahtiajakojen välttäminen ja monimuotoisempi ymmärrys maailmasta ovat tavoitettavissa tarkastelemalla tietämistä ja olemassaoloa yhteenkietoutuneina prosesseina (Barad 2008, 147). Snellman-korkeakoulun opetussuunnitelmassa yksi keskeinen osa-alue on tunnealueen kehittäminen. Sen pyrkimyksenä on rikastaa mielikuvitusta, kokemista ja tuntemista taiteellisen oppimisprosessin kautta. Sekä tunnealueen kehittämisessä että esteettisellä osaamisalueella oleellisessa roolissa ovat oppimisprosessi ja aisteihin pohjautuva kokeminen. Tunnealueella oppiminen ja esteettinen osaaminen muistuttavat toisiaan, sillä molemmissa merkittävää on tietämisen siirtäminen sivuun ja kokemukseen asettuminen.

Kokkonen (2014) hahmottaa posthumanismin ajattelutavaksi, jonka kautta ihmisen on mahdollista asettua ei-inhimillisen rinnalle maailmaan, jonka nykyistä elämää, tiedettä ja taidetta ekokriisit muovaavat. Tämä tarkoittaa myös asettautumista tilaan, jossa ihminen on sekä tietoinen oman lajinsa vaikutuksista maapallolla että tietämätön tulevan suhteen (Kok konen 2014, 179). Opetussuunnitelmissa läsnä oleva kokemuksellinen ulottuvuus sekä ajatus posthumanismista inhimillisen tietämättömyyden kohtaamisena voisivat tarjota maaperän myös inhimillisen ja ei-inhimillisen suhteen uudelleen ajattelulle.

Opetussuunnitelmissa on tyypillistä käsitellä oppimista ja kehitystä ainoastaan inhimillisten suhteiden näkökulmasta. Ihmisyyden ja ihmisyhteisöjen korostaminen häivyttää oppimisen ja kasvamisen verkostomaisia ulottuvuuksia, joissa vaikuttavat sekä inhimilliset että ei-inhimilliset tekijät. Värrin (2018) mukaan ihmiskeskeinen, kahtiajakautunut maailmankuva on vakiintunut elämisemme perustaksi. Tässä maailmankuvassa ihminen on tietoinen toimija, muu maailma taas tietoisuuden kohde. Ihmiskeskeisen maailmankuvan pohjalta rakentuva ihmisen maailmasuhde on omistava, hallitseva ja hyödyntävä. Laskelmoivaan maailmasuhteeseen liittyy esimerkiksi kritiikitön optimismi teknologian ja kehityksen suhteen. (Värri 2018, 13-14.) Häivyttävä suhde rakentuukin paitsi modernin ja kriittisen inhimillisen myös ongelmattomana näyttäytyvän ei-inhimillisen varaan.

\section{Ongelmaton ei-inhimillinen resurssi häivyttävässä suhteessa}

Häivyttävää suhdetta rakentaa myös ei-inhimillisen näyttäytyminen ongelmattomana oppimisen resurssina. Esimerkiksi erilaiset oppimisympäristöt sekä tieto- ja viestintäteknologia näyttäytyvät joustavana ja ihmisen tahtoon taipuvana apuvälineenä. Ei-inhimillinen vaikuttaa kuitenkin olevan merkittävässä roolissa koulutuksessa ja kasvatuksessa. Tulkitsemme, että tämä asema on seurausta puhdistamisen prosessista, jossa ihminen kuvataan aktiivisena toimijana ja erotetaan muusta ympäristöstä. Puhdistamisen prosessissa valikoidaan ja ilmaistaan, mikä on arvokasta ja mikä ei ole arvokasta. Puhdistamisen seurauksena tietyt 
asiat on vakiinnutettu ja tunnustettu ja niihin suhtaudutaan pikemminkin itsestäänselvyyksinä kuin puhdistustyön tuloksina. (Fenwick \& Edwards 2010, 49.) Itsestäänselvyytenä pitäminen määrittääkin eniten ei-inhimillisen asemaa opetussuunnitelmissa. Inhimillisen ja ei-inhimillisen erottelu häivyttää ei-inhimillisen vaikutusta inhimilliseen elämään ja toimintaan tehden ihmisestä subjektin ja ei-inhimillisestä objektin.

Fenwickin ja Edwardsin $(2010,3)$ mukaan toimijaverkkoteoria asettaa kyseenalaisiksi kahtiajaot, jotka ovat moniulotteisten verkostojen aikaansaamia. Toimijaverkkoteorian näkökulmasta oppimis- ja toimintaympäristöt rakentuvat ihmisten ja asioiden verkostosta ja suhteista toisiinsa, eikä oppimista ja toimintaa ole olemassa tämän verkoston ulkopuolella (ks. Fenwick \& Edwards 2010, 41). Myös luokanopettajakoulutusten opetussuunnitelmista käy ilmi käsitys, jonka mukaisesti oppiva ihminen on osa moniselitteistä verkostoa. Opetussuunnitelma-aineistossa ihmisen ja oppimis- tai toimintaympäristön suhde rakennetaan kuitenkin usein sen oletuksen varaan, että ainoastaan inhimilliset toimijat ovat prosesseissa aktiivisia ja voivat vaikuttaa niiden kulkuun.

Opetuksen ja oppimisen tutkimisessa on tyypillistä rajoittaa verkoston tarkastelu tietyn tilanteen sisäisten vaikutusten arvioimiseen (Fenwick \& Edwards 2010, 52). Onkin kiinnostavaa pohtia, mitä esimerkiksi opetussuunnitelmien kuvaamilla oppimisympäristöillä tarkoitetaan, ja määrittävätkö niitä ensisijaisesti inhimilliset ulottuvuudet vai otetaanko niiden tarkastelussa huomioon myös ei-inhimilliset tekijät.

Oppiminen on kontekstisidonnaista, elinikäistä, elämänlaajuista, formaalia tai informaalia. Ihminen oppii erilaisissa ympäristöissä, esimerkiksi kotona, päivähoidossa, koulutuksessa, työssä ja harrastuksissa. Kyky eritellä oppimisympäristöjä on tarpeen oppimisen luonteen ymmärtämiselle ja esteettömien oppimisympäristöjen rakentamiselle.

Kasvun ja oppimisen ohjaaminen rakentuu oppijoiden kehitysvaiheen ja yksilöllisten ominaisuuksien tunnistamiselle ja huomioimiselle sekä oppimisympäristön analyysille. (Jyväskylän yliopisto.)

Luokanopettajien aikuiskoulutuksen toiminta-ajatuksena on kehittää laajaalaista opettajankoulutusta joustavissa oppimisympäristöissä. Koulutus on aikuiskoulutusta, jossa elinikäisen oppimisen periaatteiden mukaisesti otetaan huomioon sekä opiskelijan yksilölliset että muuttuvan yhteiskunnan tarpeet. (Kokkolan yliopistokeskus Chydenius.)

Oppimisympäristön käsite toistuu usein opetussuunnitelmien oppimista koskevissa kuvauksissa. Opetussuunnitelmien perusteella monenlaiset ympäristöt näyttävät palvelevan inhimillistä oppimista. Opetussuunnitelmissa kuvataan monin paikoin myös elinikäistä oppimista. Elinikäinen oppiminen perustuu ajatukseen, että ihmisellä on mahdollisuus oppia uusia asioita koko elämänsä ajan ja useissa eri yhteyksissä (Tuomisto 2012, 411). Elinikäisen ja elämänlaajuisen oppimisen luonteeseen kuuluu elämän ja oppimisen yhteenkietoutuminen. Fenwick ja Edwards $(2010,52)$ pohtivat, missä muodollisesta kontekstista poistunut elinikäinen ja elämänlaajuinen oppiminen oikeastaan lopulta tapahtuu. Saari $(2016,5)$ katsoo, että elinikäiseen oppimiseen liittyy myös riippumattoman, itseohjautuvan ihmiskuvan painottuminen. Elinikäisen oppimisen idea ruokkii toimeliaisuutta painottavaa ihmiskäsitystä. Vaikka oppimisen elinikäisyyteen kietoutuva ihmiskuva voi vapauttaa yksilöitä ajattelunsa kehittämiseen, on tärkeää arvioida myös sen tuottaman ihmiskäsityksen ja ei-inhimilliseen välineellisesti suhtautumisen yhteyttä. 
Oppimisympäristöjen ja oppimisen apuvälineiden oletetaan olevan passiivisia ja inhimilliseen tahtoon taipuvia. Latour $(2005,39)$ nimittää mustaksi laatikoksi verkoston toimijaa, jonka odotetaan toimittavan tehtäviään neutraalisti, ja jota pidetään yhtenä kokonaisuutena, vaikka se rakentuu monista osista. Esimerkki mustasta laatikosta on tietokone, jonka oletetaan toimittavan tietyt tehtävät käskyjen perusteella. Monilla on kuitenkin kokemus tietokoneesta, joka ei toimi oletetusti ja vaikuttaa siten huomattavasti työskentelyn kulkuun. Hakkarainen $(2006,14)$ toteaa, että teknologia järjestelmineen on parantanut inhimillistä tiedonkäsittelyä monin tavoin. Näiden älyllisten proteesien toimintaa pidetään yleensä itsestäänselvyytenä lukuun ottamatta tilanteita, joissa ne eivät toimi toivotulla tavalla. Inhimillinen toimijuus on monilta osin näiden proteesien suorituksista riippuvainen. (Hakkarainen 2006, 14-15.) Opetussuunnitelmissa inhimillisen toiminnan riippuvuus ei-inhimillisistä välineistä häivyttyy. Kuitenkin niihin kohdistuvien odotusten myötä välineet tulevat oleelliseksi osaksi oppimisprosesseja ja yhteistä toimintaa.

Opiskelija tunnistaa ja osaa huomioida erilaisten oppijoiden tarpeita ja oppimisprosessin jatkumon ohjaamiseen liittyviä toimintatapoja yhteisöllisen oppimisen suunnittelussa ja toteutuksessa eri toiminta- ja oppimisympäristöissä. Opiskelija osaa käyttää opetusteknologioita yhteisöllisen oppimisen välinei$n \ddot{a}$. (Itä-Suomen yliopisto.)

Åkermanin (2006, 38-39) mukaan toimijaverkkoteoria johdattaa ajattelemaan todellisuuden muodostuvan käännöksistä, joiden seurauksena syntyy esimerkiksi vakiintuneita verkostoja, auktoriteettiasemia ja näennäistä yksiäänisyyttä. Opetussuunnitelmissa ei-inhimillisen asemaa koulutuksen osana luonnehtii monin paikoin juuri itsestäänselvyyden ja yksinkertaisuuden vaikutelma, vaikka samanaikaisesti syntyy kuva oppimisprosesseista ja ympäristöistä, jotka rakentuvat hyvin moninaisista aineksista.

Luokanopettajien aikuiskoulutuksessa opettajaksi opiskeleville tarjotaan uusimpaan tutkimukseen perustuvia menetelmiä ja malleja tieto- ja viestintätekniikan opetuskäytöstä ja median hyödyntämisestä opiskelussa ja opetuksessa. (Kokkolan yliopistokeskus Chydenius.)

Ei-inhimillisten voi ajatella välittävän oppimista ja toimintaa koulutuksessa. Kiinnostavaa onkin juuri se, miten ne tuon välittämisen toteuttavat (ks. Saari \& Harni 2015, 43). Luokanopettajakoulutusten opetussuunnitelmien kontekstissa oppimisympäristöille tai oppimisen välineille, kuten teknologialle, on delegoitu oppimiseen liittyviä tehtäviä, mutta lopulta toimijuus ja koulutuksessa käsiteltävät ilmiöt näyttäytyvät vain inhimillisinä.

Vuorovaikutus on ilmiö, jossa tarkastellaan ihmisiä suhteessa toisiinsa. Se kietoutuu kasvatusalan koulutukseen ja siinä rakentuvaan kasvatusalan asiantuntijuuteen monella tavalla: (1) osaamisena, (2) osallisuutena ja osallistumisena sekä (3) kohtaamisen tiloina. Ilmiön tutkimisessa nämä tarkastelunäkökulmat limittyvät ja täydentävät toisiaan. Ilmiötä tarkastellaan lapsuuden, nuoruuden ja aikuisuuden formaaleissa ja informaaleissa oppimisympäristöissä. Tieto- ja viestintäteknologian merkitys ilmiön eri ulottuvuuksissa on olennainen. (Jyväskylän yliopisto.)

Tieto- ja viestintäteknologian käyttö mainitaan monin paikoin oppimisprosessien osaksi. Häivyttämällä rakentuva inhimillisen ja ei-inhimillisen suhde herättää kysymyksen siitä, mikä on ei-inhimillisen rooli oppimisprosesseissa. Inhimillisen oppimisen ja sen vaatimien resurssien suhdetta olisi syytä tarkastella vailla oletusta tämän suhteen yksinkertaisuudesta. 
Toimijaverkkoteoriassa toimijasuhteiden ajatellaan syntyvän suhteessa toisiinsa, ja toimijat nähdään sekä toiminnan kohteena että sen lähteenä (Latour 2005, 39). Tämä ajattelutapa haastaa käsitystä toiminnan subjektien ja objektien yksiselitteisyydestä.

Opetussuunnitelmien perusteella inhimillinen oppiminen on siirrettävissä erilaisiin yhteyksiin ja kehitettävissä monin eri tavoin. On kuitenkin vastaansanomatonta, että oppiminen ja koulutus ovat myös riippuvaisia sellaisista ei-inhimillisistä resursseista, jotka eivät ole täysin ihmisen hallinnassa. Tätä näkökulmaa enemmän opetussuunnitelmissa painottuvat erilaiset koulutuksen tarjoamat mahdollisuudet, eikä ei-inhimillisen luonnon rajoittavia tekijöitä juuri huomioida.

Tavoitteena on, että opiskelija harjaantuu yhteistyöhön kouluyhteisön jäsenten, oppilaiden vanhempien ja koulun eri sidosryhmien kanssa. Koulutus tarjoaa opiskelijalle mahdollisuuksia rakentaa tutkivaa ja kehittävää työotetta, omaksua opetettavat ydinsisällöt sekä taitoja ja valmiuksia suunnitella kaikkia oppijoita osallistavia pedagogisesti mielekkäitä oppimiskokonaisuuksia ja -ympäristöjä. (Kokkolan yliopistokeskus Chydenius.)

Luokanopettajakoulutuksen kuvaaminen lähinnä inhimillisten resurssien ja ihmisten välisen yhteistyön kautta on humanistisen perinteen valossa ymmärrettävää. Toisaalta ei-inhimillisten resurssien ja toimijoiden ongelmattomana pitäminen on huomionarvoista, koska ne ovat perimmäinen pohja, joiden varaan elämä ja oppiminen rakentuvat. Latour (1993, 34) katsoo, että moderniuden säännöstöön kuuluu piirre häivyttää inhimillisen ja ei-inhimillisen yhdistelmät näkyvistä, vaikka moderni elämä kuitenkin laajalti perustuu niiden toimintaan. Häivyttävässä suhteessa käsitys modernista, aktiivisesta inhimillisestä ja passiivisesta ei-inhimillisestä liittyvätkin voimakkaasti yhteen.

\section{Tunnustava suhde}

Inhimillisen ja ei-inhimillisen välille rakentuu aineistossa myös tunnustava suhde. Tunnustavassa suhteessa ei-inhimillisen merkitystä on sanallistettu ja painotettu selkeämmin kuin häivyttävässä suhteessa. Toimijaverkkoteorian näkökulmasta läsnä ovat sekä puhdistamisen että kääntämisen prosessit. Tunnustava suhde rakentuu, kun opetussuunnitelmissa ovat näkyvillä inhimillisen korostamisen lisäksi myös inhimillisen ja ei-inhimillisen muodostamat verkostot.

Tunnustava suhde inhimillisen ja ei-inhimillisen välille rakentuu Snellman-korkeakoulun, Lapin yliopiston luokanopettajakoulutuksen ja Itä-Suomen yliopiston luokanopettajakoulutuksen opetussuunnitelmissa. Näissä opetussuunnitelmissa inhimillisen ja ei-inhimillisen luonnon välille muodostuu suhde, jossa inhimillisyyttä korostavan sivistysprojektin rinnalla sanallistetaan ei-inhimillisen merkitystä. Tunnustamisella tarkoitamme juuri sitä, että sekä puhdistamisen että kääntämisen prosessin seurauksia sanallistetaan. Tunnustavassa suhteessa läsnä ovat sekä inhimillisen ja ei-inhimillisen erottelut että niiden yhdistelmät. Yhdistelmissä korostuu inhimillisen ja ei-inhimillisen rinnakkaiselo.

Tavoitteena on kouluttaa vahvoja pedagogiikan ja didaktiikan asiantuntijoita, jotka osaavat toimia luovasti ja joustavasti muuttuvissa olosuhteissa sekä yhteistoiminnallisesti niin ammattiryhmän sisällä kuin moniammatillisessa yhteistyössäkin. Opiskelijoita tuetaan oman opettajaidentiteetin ja pedagogiikan sekä laaja-alaisen, tutkivan ja kehittyvän opettajuuden rakentamisessa. Koulutuksessa huomioidaan pohjoisen kulttuuriset, taloudelliset ja maantieteelliset erityispiirteet. (Lapin yliopisto.) 
Maantieteellinen sijainti näyttää olevan yhteydessä inhimillisen ja ei-inhimillisen suhteen rakentumiseen opetussuunnitelmissa. Lapin ja Itä-Suomen yliopistojen luokanopettajakoulutusten opetussuunnitelmissa ei-inhimillinen luonto ja sen määrittämät ehdot huomioidaan osana koulutuksen lähtökohtia. Voi kysyä, onko ei-inhimillisen luonnon kohtaaminen ja eiinhimillisen merkitys harvaan asutuilla seuduilla konkreettisemmin läsnä kuin suurempien paikkakuntien arjessa.

Ihmiselämä tulisikin ymmärtää yhtäaikaisesti taloudellisiin, ekologisiin ja sosiaalisiin tekijöihin pohjautuvana toimintana, jossa eri tekijät ovat toisistaan riippuvaisia. Taloudellisten, ekologisten ja sosiaalisten ulottuvuuksien käsitteleminen toisistaan erillisinä todellisuuden osina voi johtaa kapeisiin näkemyksiin olemassaolon luonteesta. (Salonen \& Bardy 2015,7 .) Lisäksi on tärkeää keskittyä näiden tekijöiden välisten hierarkioiden tarkasteluun ja käsittää osa-alueet kokonaisena systeeminä, jonka sisällä toiminta yhdellä osa-alueella vaikuttaa myös muihin osa-alueisiin (Salonen \& Bardy 2015, 10). Merkittävää maantieteellisessä ulottuvuudessa on se, että koulutuksen osoitetaan kytkeytyvän inhimillisen lisäksi myös osaksi ei-inhimillistä maailmaa, eikä se sulje pois myöskään globaalia näkökulmaa. Esimerkiksi Itä-Suomen yliopiston luokanopettajakoulutuksen opetussuunnitelman mukaan opiskeltavissa ilmiöissä risteävät sekä paikallisuuden että maailmanlaajuisuuden näkökulmat. Koulutuksessa tavoitteena on ymmärtää niiden suhdetta sekä linkittää monikulttuurisuus ja kansainvälisyys kestävän tulevaisuuden rakentamiseen.

Martusewicz, Edmundson ja Lupinacci (2011) viittaavat käsitteellä "place-based education" opiskeluun, jossa oppiminen tapahtuu omassa lähiympäristössä ja -yhteisössä, ja sitä kautta myös merkityksellistyy oppijoille. Tällaisen oppimisen näkökulmasta sekä inhimilliset yhteisöt että ei-inhimillinen luonto ovat vuorovaikutuksessa keskenään, ja oppimisprosessit ovat sidoksissa paitsi paikalliseen ihmisyhteisöön myös paikalliseen ympäristöön. (Martusewicz ym. 2011, 15.) Erityisesti Lapin yliopiston opetussuunnitelmassa kuvataan tämänkaltaista opiskelun ja oppimisen kytkeytymistä paikallisuuteen.

Snellman-korkeakoulu kouluttaa luokanopettajia steinerkouluihin. Sen opetussuunnitelmassa on muiden opetussuunnitelmien lailla humanistinen painotus, mutta siinä sanallistetaan humanistisia lähtökohtia ja korostetaan yksilön toimintaa oppimisprosessissa muita opetussuunnitelmia voimakkaammin.

Todellinen oppimistapahtuma on aina ihmisen omaa sisäistä toimintaa, sisäistä aktiivisuutta. Sekä lapsen että aikuisen kehittyminen on oman ponnistelun, itsekasvatuksen tulosta. Itsekasvatus on tietoista toimintaa, joka pohjautuu itsensä tuntemiseen, tekojensa arvioimiseen ja omien kasvuhaasteidensa etsimiseen. (Snellman-korkeakoulu.)

Oppimisen nähdään rakentuvan ihmisyksilön tekojen varaan, eikä sen verkostomaisia ulottuvuuksia huomioida. Samalla kun koulutuksen opetussuunnitelmassa painotetaan inhimillistä sivistystä ja aktiivisuutta, se kuvaa myös sitä, kuinka ei-inhimillinen on läsnä koulutuksen arjessa.

Kyky ottaa vastuuta ympäristöstä ja luonnosta tarvitsee ihmisen kokonaisvaltaista tiedostamista ja toimintaa. Käytännössä Snellman-korkeakoulun opiskelijat huolehtivat yhdessä opettajien ja muun henkilökunnan kanssa tiloista, ympäristöstä sekä puutarhasta. Tavoitteena on opiskelijan vastuuntunnon herättäminen ympäristöstä ja luonnosta. Opettajan työn eräs keskeinen haaste on ympäristökasvatus. (Snellman-korkeakoulu.) 
Vastuuseen ei-inhimillisestä pyritään kasvattamaan koulutuksen käytännössä, jossa inhimillinen huolenpito ja ei-inhimillinen kasvu kohtaavat. Ei-inhimillinen on koulutuksen jokapäiväisessä arjessa läheinen ja huomioon otettava olemassaolon muoto. Menetelmällisenä valintana puutarhanhoito voi olla yksinkertainen tapa lisätä ymmärrystä inhimillisen ja eiinhimillisen suhteesta. Poikkeuksellisen puutarhanhoidosta kuitenkin tekee se seikka, että vaikka huolenpito ja kasvattaminen kuuluvat aina oleellisesti luokanopettajakoulutukseen, niitä kohdistetaan yleensä ainoastaan inhimilliseen olemassaoloon.

Ottamalla ei-inhimillinen elämä opetuksen keskiöön on mahdollista kohdata se, ettei inhimillistä ole ilman ei-inhimillistä. Ei-inhimilliset mahdollistavat ihmisen olemassaolon, mutta eivät kuitenkaan ole täällä ihmistä varten (ks. Snaza \& Weaver 2015, 8). Ihminen on muusta luonnosta riippuvainen, mutta muu luonto puolestaan ei varsinaisesti tarvitse ihmis tä, vaan ekologisia kasvun edellytyksiä. Opetussuunnitelman perusteella ei voi sanoa, millaista keskustelua puutarhanhoidon yhteydessä käydään, mutta lähtökohtaisesti se mahdollistaa monipuolisen pohdinnan inhimillisen ja ei-inhimillisen suhteesta. Pedagogisten valintojen voi olettaa paitsi kertovan käsityksistä ja arvoista, myös rakentavan niitä (Mustola 2019, 7).

Lapin yliopiston luokanopettajakoulutuksessa opiskelijoilla on mahdollisuus opiskella luontokasvatukseen painottuneessa koulutuksessa. Tärkeää tässä yhteydessä on, miten "luonto" määritellään ja miten ihmisen asema luonnossa nähdään (ks. Haraway 2008, 167). Luontokasvatuspainotteisen luokanopettajakoulutuksen voi nähdä sekä esimerkkinä "ihminen ja luonto" -kahtiajaosta että mahdollisuutena rakentaa näiden suhdetta tuomalla ei-inhimillinen näkyvästi osaksi koulutusta.

\section{Luontokasvatuspainotteisen luokanopettajakoulutuksen tavoitteena on koulut- taa opettajia, jotka ymmärtävät luonnon merkityksen inhimilliselle kasvulle ja oppimiselle ja omaavat luontokasvatuksen toteuttamisessa tarvittavia tiedolli- sia, taiteellisia ja taidollisia valmiuksia. Koulutus kehittää valmiuksia toteut- taa luontokasvatukseen liittyviä pedagogisia projekteja ja niveltää oppimista lähiluontoon ja kulttuuriin. Lisäksi koulutus antaa valmiuksia koulun ulko- puolisten oppimisympäristöjen, kuten tiedekeskusten ja museoiden hyödyntä- miseen perusopetuksessa. Koulutuksen jälkeen opettajat osaavat toimia eetti- sesti ja rakentavasti muuttuvissa kasvu- ja toimintaympäristöissä. (Lapin yli- opisto.)}

Luontokasvatuspainotteisen koulutuksen olemassaolon voi itsessään nähdä puhdistamisen prosessin tuloksena. Sen opetussuunnitelmassa kuitenkin sanallistetaan ei-inhimillisen merkitys inhimilliselle kehitykselle. Toimijaverkkoteorian näkökulmasta inhimilliset pyrkimykset ja järjen käyttö ohjaavat todellisuuden rakentumista vain osittain. Tätä ajattelutapaa seuraten prosessit muuttuvat ihmisen yksinään hallitsemista tapahtumaketjuista monien erilaisten vaikutusten verkostoiksi. (Lummaa \& Rojola 2014, 24.) Koulutusta, kasvatusta ja oppimista ei voi tästä näkökulmasta tarkastella ainoastaan inhimillisenä toimintana, vaan myös niihin vaikuttavat ei-inhimilliset tekijät on otettava yhtä lailla huomioon.

Snellman-korkeakoulun ja Lapin yliopiston opetussuunnitelmissa ei-inhimillisen merkitys inhimilliselle kasvulle ja kehitykselle tulee esiin selkeämmin kuin muissa opetussuunnitelmissa. Snellman-korkeakoulun ja Lapin yliopiston opetussuunnitelmissa rakentuvassa tunnustavassa suhteessa painottuvat tekemisen ja kokemisen merkitys. 


\section{Pohdinta}

Tutkimuksen tarkoituksena oli tarkastella inhimillisen ja ei-inhimillisen suhdetta luokanopettajakoulutusten opetussuunnitelmissa erityisesti posthumanistisesta näkökulmasta. Tutkimusta motivoi kiinnostus koulutuksen lähtöoletusten analysoimiseen ja pohtimiseen. Opetussuunnitelmissa inhimillisen ja ei-inhimillisen suhde rakentuu joko ei-inhimillisen häivyttämisen tai sen tunnustamisen kautta, hienovaraisten oletusten keinoin. Ihminen näyttäytyy pääosin aktiivisena toimijana ei-inhimillisen toimittaessa resurssin virkaa. Posthumanismissa taas ihmisen ja ympäristön suhde nähdään vailla tällaista valtasuhdetta (Tammi \& Hohti 2017, 72).

Ihmiskeskeisyydestä irrottautumisen ongelma on juuri siinä, että koko länsimainen filosofia ja maailmankatsomus perustuvat ihmiskeskeisyydelle (Oksanen 2012, 164). Ihmiskeskeisyydestä irti pyrkimisen sijaan tulisikin tarkastella kriittisesti siitä johdettuja lähtöoletuksia sekä sitä, miten nämä lähtöoletukset vaikuttavat inhimillisen ja ei-inhimillisen suhteen rakentumiseen. Taipumus erotella inhimillinen ja ei-inhimillinen toisistaan olemuksensa perusteella on posthumanistisen kritiikin ydinkohteita (Lummaa 2010, 23-24). Luokanopettajakoulutuksen ihmiskeskeisyyttä sekä voimakasta inhimillisen ja ei-inhimillisen erottelua selittää osaltaan se, että koulutuksen keskeisenä sisältönä on inhimillinen kasvu, kehitys ja oppiminen.

Ei-inhimillisen osuus jää yleensä huomioimatta kasvatustieteen kehittymistä käsiteltäessä. Kuitenkin ei-inhimillisen ja inhimillisen vuorovaikutus on ollut tärkeässä roolissa kasvatustieteellisen tiedon lisäämisessä. (Saari \& Harni 2015, 51-52.) Onkin kiinnostavaa tarkastella, missä määrin ei-inhimillisen, kuten luonnon, eläinten ja teknologian, merkitystä käsitellään koulutuksessa. Kysymys inhimillisten ja ei-inhimillisten elämänmuotojen yhteenkietoutuneisuudesta on yhä ajankohtaisempi luonnonresurssien niukentuessa sekä ilmastonmuutoksen ja ympäristöongelmien vaikuttaessa yhä voimakkaammin elämään maapallolla.

Nykytilanteessa oppimisen ajatellaan laajentuvan mitä moninaisimmin välinein mitä monimutkaisimpiin konteksteihin. Erityisesti tieto- ja viestintäteknologiaa hyödynnetään perusopetuksessa laajasti ja kattavasti (POPS 2014, 23). Teknologian tehtävä oppimisprosesseissa ja -ympäristöissä on yleensä edistää inhimillistä oppimista. Inhimillisten ja ei-inhimillisten voi ajatella muodostavan nykykoulutuksessa verkostoja, joilla on oppimistavoitteiden toteuttamisessa tärkeä rooli. Tästä näkökulmasta myös ei-inhimillisiin toimijoihin ja niiden ennakoimattomiinkin vaikutuksiin tulisi kiinnittää koulutuksen verkostoissa nykyistä enemmän huomiota. Perusopetuksessa käsitelläänkin myös vastuullista ja kestävää teknologian käyttöä sekä pyritään lisäämään oppilaiden ymmärrystä teknologian monimuotoisuudesta ja merkityksestä (POPS 2014). Myös opettajankoulutuksessa on tärkeää huomioida teknologian hyödyntämisen ohella sen esiin tuomia ongelmia. Kritiikittömyys tiedettä ja teknologiaa kohtaan vahvistaa ajattelutapaa, jonka mukaisesti ihminen hallitsee luontoa ja kykenee ratkaisemaan eteen tulevat ongelmat. Ratkaisuja ei kuitenkaan synny, mikäli tieteelle ja teknologialle ei ole lisäksi olemassa yhteiskunnallisia rakenteita, joissa ne toimivat. (Lähde 2013, 162.) Teknologia itsessään ei ole avain ratkaisuihin, vaan avainkysymys on, missä ja miten teknologiaa käytetään.

Veli-Matti Värrin (2018) mukaan opettajankoulutuslaitosten opetussisällöt ja toiminnalliset puitteet tulisi nykyisin rakentaa kriittisen ja ekologisen lähtökohdan pohjalta. Ekologinen kriisi olisi hyväksyttävä opettajankoulutuksen järjestämistä ensisijaisesti määrittäväksi tilanteeksi. Opettajankoulutukseen sisältyisi esimerkiksi ihmisen maailmasuhteen, ihmisen 
ja teknologian suhteen sekä kokemusmaailmaamme kuuluvien vaikeiden ja epämiellyttävien ilmiöiden, kuten ilmastonmuutoksen, käsittelyä. (Värri 2018, 134, 136-137.)

Luokanopettajakoulutuksen opetussuunnitelmissa kuvatussa kriittisyydessä piilee mahdollisuus nykyisen koulutuksen ja kasvatuksen lähtökohtien kyseenalaistamiseen sekä inhimillisen toiminnan itsekritiikkiin. Toisaalta modernin opettajankoulutuksen lähtökohdat nojaavat pitkälti aktiiviseen, hallitsevaan ja hyödyntävään asenteeseen, jonka voi katsoa myös aiheuttavan ihmisyyden korostamista. Sekä opetussuunnitelmissa kuvattuun kriittiseen asenteeseen että posthumanismiin kuuluu itsestäänselvyyksien kyseenalaistaminen. Luokanopettajakoulutuksessa näiden ajattelutapojen yhdistäminen olisi hedelmällinen lähtökohta tarkastella elämisemme perustalla vallitsevia sitoumuksia. Tällainen kriittisyys on kuitenkin käytännössä haastavaa, koska kritiikin kohteena olevat lähtökohdat ovat voimakkaasti ajatteluumme juurtuneita.

Jos modernin inhimillisen ja ei-inhimillisen erottelu kyseenalaistetaan, on perusteet ihmisen vallankäytölle johdettava muualta kuin tästä eronteosta. Oleellista onkin paitsi pohtia ei-inhimillisten yhteiskunnallista asemaa uudelleen, myös käsittää erilaisten valtasuhteiden ja vallankäytön muotojen syntymistä modernin ihmisyyden kautta (Latour 1993, 11-12). On siis oleellista ottaa huomioon moderni ihmisyys osana inhimillisen ja ei-inhimillisen suhteen rakentumista.

Posthumanistinen ja verkostomainen lähtökohta oppimisympäristöjen ja -prosessien arviointiin on tarpeellinen. Jatkossa olisi oleellista tutkia esimerkiksi, millaisia toimijoita oppimistilanteisiin osallistuu, miten ne siellä toimivat ja millaisia suhteita niiden välille muodostuu. Keskeinen kysymys on, miten kohtaamiset ei-inhimillisen kanssa voivat vaikuttaa koulutuksessa kehittyvään yhteiskunnalliseen ja eettiseen osaamiseen. Miten koulutus esimerkiksi vaikuttaa käsityksiin siitä, kuka ansaitsee huolenpitoa tai mikä ei-inhimillisen asema tulisi yhteiskunnassa olla? Luokanopettajakoulutusta tutkittaessa kiinnostavaa on se, miten inhimillisen ja ei-inhimillisen suhdetta käsittelevä opetus vaikuttaa opiskelijoiden eettisiin ja yhteiskunnallisiin käsityksiin.

\section{Lähteet}

Helsingin yliopiston luokanopettajakoulutuksen opetussuunnitelma [käytöstä poistunut www-lähde]. Tiedosto kirjoittajien hallussa (tallennettu 8.2.2018).

Helsingin yliopiston luokanopettajakoulutuksen opetussuunnitelma [käytöstä poistunut www-lähde]. Tiedosto kirjoittajien hallussa (tallennettu 8.2.2018).

Helsingin yliopiston luokanopettajakoulutuksen opetussuunnitelma [www-lähde]. < https:// weboodi.helsinki.fi/hy/vl kehys.jsp?

$\underline{\text { Kieli }=1 \& M D 5 a v a i n=\& v 1 \text { tila }=2 \& O p a s=5435 \& O r g=116715340}>($ luettu 8.2.2018).

Helsingin yliopiston luokanopettajakoulutuksen opetussuunnitelma [www-lähde]. < https:// weboodi.helsinki.fi/hy/vl kehys.jsp?

$\underline{\text { Kieli=1\&MD5avain }=\& v 1 \text { tila=2\&Opas }=5447 \& O r g=118077949}>$ (luettu 8.2.2018).

Itä-Suomen yliopiston luokanopettajakoulutuksen opetussuunnitelma [www-lähde]. < https://www.uef.fi/documents/288123/380329/Luokanopettaja_ja lokoma_OPS 20142017.pdf/d012df4a-9523-4b0b-a3b5-b4d35cee4241 > (luettu 6.11.2017).

Jyväskylän yliopiston luokanopettajakoulutuksen opetussuunnitelma [www-lähde]. < https://www.jyu.fi/ops/fi/edupsy/opettajankoulutuksen-lahtokohta-ja-tavoitteet $>$ (luettu 6.11.2017). 
Jyväskylän yliopiston luokanopettajakoulutuksen opetussuunnitelma [www-lähde]. < https://www.jyu.fi/ops/fi/edupsy/opettajankoulutuksessa-opiskeltavat-ja-tutkittavat-il$\underline{\text { miot }}>$ (luettu 6.11.2017).

Jyväskylän yliopiston Kokkolan yliopistokeskus Chydeniuksen luokanopettajien aikuiskoulutuksen opetussuunnitelma [www-lähde]. $<$ https://www.chydenius.fi/opiskelu/luokanopettajien-aikuiskoulutus/ops-2014-2017 > (luettu 24.11.2017).

Lapin yliopiston luokanopettajakoulutuksen opetussuunnitelma [www-lähde].

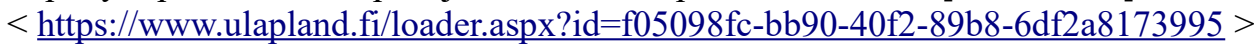
(luettu 5.12.2017).

Oulun yliopiston luokanopettajakoulutuksen opetussuunnitelma [www-lähde]. < $\underline{\text { https:// }}$ weboodi.oulu.fi/oodi/vl kehys.jsp?

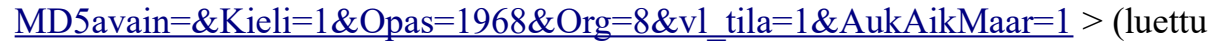
24.11.2017).

Snellman-korkeakoulun luokanopettajakoulutuksen opetussuunnitelma [käytöstä poistunut www-lähde]. Tiedosto kirjoittajien hallussa (tallennettu 5.12.2017).

Turun yliopiston luokanopettajakoulutuksen opetussuunnitelma [www-lähde]. < https:// nettiopsu.utu.fi/opas/tutkintoOhjelma.htm?rid=30454\&uiLang=fi\&lang=fi\&lvv=2017 > (luettu 13.2.2018).

Turun yliopiston luokanopettajakoulutuksen opetussuunnitelma [www-lähde]. < https:// nettiopsu.utu.fi/opas/tutkintoOhjelma.htm?rid=30455\&uiLang=fi\&lang=fi\&lvv=2017 > (luettu 13.2.2018).

Turun yliopiston luokanopettajakoulutuksen opetussuunnitelma, Rauman yksikkö [wwwlähde]. $<$ https://nettiopsu.utu.fi/opas/tutkintoOhjelma.htm?

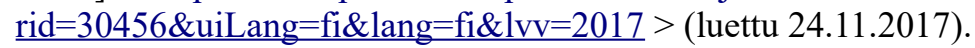

Turun yliopiston luokanopettajakoulutuksen opetussuunnitelma, Rauman yksikkö [wwwlähde]. $<$ https://nettiopsu.utu.fi/opas/tutkintoOhjelma.htm?

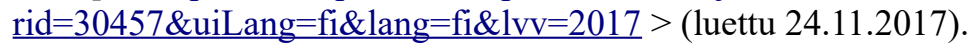

\section{Kirjallisuus}

Apple, Michael W. 2010. Curriculum studies, the future of: Essay 1. Teoksessa Kridel, Craig A. (toim.) Encyclopedia of curriculum studies. Thousand Oaks: Sage, 237-238.

Autio, Tero, Hakala, Liisa \& Kujala, Tiina (toim.) 2017. Opetussuunnitelmatutkimus. Keskustelunavauksia suomalaiseen kouluun ja opettajankoulutukseen. Tampere University Press [www-lähde]. < http://tampub.uta.fi/bitstream/handle/10024/102624/ Autio ym Opetussuunnitelmatutkimus.pdf?sequence $=1$ \&isAllowed $=\mathrm{y} \quad>\quad$ (luettu 13.4.2019).

Barad, Karen 2008. Posthumanist Performativity: Toward an understanding of how matter comes to matter. Teoksessa Alaimo, Stacy \& Hekman, Susan (toim.), Material Feminisms. Bloomington, IN: Indiana University Press, 120-154.

Britzman, Deborah 2003. Practice makes practice: A critical study of learning to teach. Revised edition. Albany: SUNY Press.

Britzman, Deborah 2009. Very thought of education: Psychoanalysis and the impossible professions. Albany: SUNY Press.

Fenwick, Tara \& Edwards, Richard 2010. Actor-network theory in education. New York: Routledge. https://doi.org/10.4324/9780203849088 
Goodson, Ivor F. 2001. Opetussuunnitelman tekeminen. Esseitä opetussuunnitelman ja oppiaineen sosiaalisesta rakentumisesta. Suomentanut Erja Moore. Englanninkielinen alkuteos 1995. Joensuu University Press.

Hakkarainen, Kai 2006. Kollektiivinen älykkyys. Esitelmä Mensan juhlaviikon tilaisuudessa 16.11.2006, Vernissa, Tikkurila [www-lähde]. < http://www.helsinki.fi/science/networkedlearning/material/KaiHakkarainenKollektiivinen.pdf $>$ (luettu 13.5.2019).

Haraway, Donna 2008. Otherworldly conversations, terran topics, local terms. Teoksessa Alaimo, Stacy \& Hekman, Susan (toim.), Material Feminisms. Bloomington, IN: Indiana University Press, 157-187.

Kokkonen, Tuija 2014. Kun emme tiedä. Keskustelemassa "meitä” uusiksi: lajienväliset esitykset ja esitystaiteen rooli ekokriisien aikakaudella. Teoksessa Lummaa, Karoliina \& Rojola, Lea (toim.), Posthumanismi. Turku: Eetos, 179-209.

Latour, Bruno 2006. Emme ole koskaan olleet moderneja. Englanninkielisestä versiosta suomentanut Risto Suikkanen. Ranskankielinen alkuteos 1991. Jyväskylä: Vastapaino.

Latour, Bruno 2005. Reassembling the Social: An Introduction to Actor-Network-Theory. New York: Oxford University Press.

Latour, Bruno 1993. We have never been modern. Kääntänyt Catherine Porter. Ranskankielinen alkuteos 1991. Cambridge: Harvard University Press.

Lehtonen, Turo-Kimmo 2008. Aineellinen yhteisö. Helsinki: Tutkijaliitto.

Lummaa, Karoliina 2014. Antroposeeni ja objektien ekologia. Ihmisen luontosuhde humanismin jälkeen. Teoksessa Lummaa, Karoliina \& Rojola, Lea (toim.), Posthumanismi. Turku: Eetos, 265-288.

Lummaa, Karoliina 2010. Poliittinen siivekäs. Lintujen konkreettisuus suomalaisessa 1970-luvun ympäristörunoudessa. Jyväskylä: Nykykulttuurin tutkimuskeskuksen julkaisuja 102.

Lummaa, Karoliina \& Rojola, Lea 2014. Johdanto: Mitä posthumanismi on? Teoksessa Lummaa, Karoliina \& Rojola, Lea (toim.), Posthumanismi. Turku: Eetos, 13-32.

Lähde, Ville 2013. Niukkuuden maailmassa. Tampere: niin \& näin.

Martusewicz, Rebecca A., Edmundson, Jeff \& Lupinacci, John 2011. Ecojustice Education. Toward Diverse, Democratic and Sustainable communities. New York: Routledge.

Mustola, Marleena 2019. Why is a live chicken banned from the kindergarten? Two lessons learned from teaching posthuman pedagogy to university students. Educational Philosophy and Theory 51 (14), 1434-1443. https://doi.org/10.1080/00131857.2018.1553712

Oksanen, Markku 2012. Ympäristöetiikan perusteet. Luonne, historia ja käsitteet. Helsinki: Gaudeamus.

POPS 2014. Perusopetuksen opetussuunnitelman perusteet 2014. Helsinki: Opetushallitus [www-lähde]. < https://www.oph.fi/sites/default/files/documents/ perusopetuksen opetussuunnitelman perusteet 2014.pdf > (luettu 13.2.2019).

Rokka, Pekka 2011. Peruskoulun ja perusopetuksen vuosien 1985, 1994 ja 2004 opetussuunnitelmien perusteet poliittisen opetussuunnitelman teksteinä. Tampereen yliopisto: Acta Electronica Universitatis Tamperensis 1076. Kasvatustieteiden yksikkö. Akateeminen väitöskirja [www-lähde]. < http://tampub.uta.fi/bitstream/handle/10024/66741/978951-44-8456-8.pdf? sequence=1\&isAllowed $>$ (luettu 25.10.2018).

Saari, Antti 2016. Elinikäinen oppiminen ja yksilöivä valta. Aikuiskasvatus 36 (1), 4-13.

Saari, Antti \& Harni, Esko 2015. Kyyhky ja opetuskone: inhimillisen ja ei-inhimillisen yhteenliittymiä B. F. Skinnerin behaviorismissa. Kasvatus \& Aika 9 (1), 41-55 [wwwlähde]._ $<$ https://journal.fi/kasvatusjaaika/article/view/68508 $>$ (luettu 3.2.2018). 
Salonen, Arto O. \& Bardy, Marjatta 2015. Ekososiaalinen sivistys herättää luottamusta tulevaisuuteen. Aikuiskasvatus 35 (1), 4-15.

Snaza, Nathan \& Weaver, John A. 2015. Introduction. Teoksessa Snaza, Nathan \& Weaver, John A. (toim.), Posthumanism and Educational Research. New York: Routledge, 1-14. https://doi.org/10.4324/9781315769165

Tammi, Tuure \& Hohti, Riikka 2017. Lasten osallistuminen ja posthumanistinen ontologia: urittuvaa ja emergenttiä kartoittamassa. Kasvatus \& Aika 11 (1), 69-83 [www-lähde]. $\leq$ https://journal.fi/kasvatusjaaika/article/view/68706/30128 > (luettu 2.6.2019).

Toikkanen, Auli 2019. Inhimillisen ja ei-inhimillisen suhde luokanopettajakoulutusten opetussuunnitelmissa. Kasvatustieteen pro gradu -tutkielma. Jyväskylän yliopisto, opettajankoulutuslaitos.

Toivanen, Tero \& Pelttari, Mikko 2017. Tämä ihmisen maailma? Planeetan hätätila, antroposeenikertomuksen kritiikki ja antroposeenin vaihtoehtoinen historia. Tiede \& edistys $42(1), 6-35$.

Tuomi, Jouni \& Sarajärvi, Anneli 2018. Laadullinen tutkimus ja sisällönanalyysi. Uudistettu laitos. Helsinki: Tammi.

Valkonen, Jarno, Lehtonen, Turo-Kimmo \& Pyyhtinen, Olli 2013. Sosiologista materiaalioppia. Sosiologia 50 (3), 217-221.

Värri, Veli-Matti 2018. Kasvatus ekokriisin aikakaudella. Tampere: Vastapaino.

Värri, Veli-Matti 2014. Halun kultivointi ekologisen sivistyksen mahdollisuutena. Teoksessa Saari, Antti, Jokisaari, Olli-Jukka \& Värri, Veli-Matti (toim.), Ajan kasvatus. Kasvatusfilosofia aikalaiskritiikkinä. Tampere University Press, 87-122 [www-lähde]. < https://tampub.uta.fi/bitstream/handle/10024/101382/

halun_kultivointi_ekologisen_sivistyksen_mahdollisuutena.pdf?sequence $=1>$ (luettu 13.2.2019).

Wolfe, Cary 2010. What is posthumanism? Minneapolis, MN: University of Minnesota Press.

Åkerman, Maria 2006. Tiedon tuotannon käytännöt ja ympäristöpoliittinen toimijuus. Rajaamisen ja yhdistämisen politiikkaa. Tampereen yliopisto: Acta Electronica Universitatis Tamperensis 513. Yhdyskuntatieteiden laitos. Akateeminen väitöskirja [wwwlähde]. < http://tampub.uta.fi/bitstream/handle/10024/67587/951-44-6576-8.pdf? $\underline{\text { sequence }=1 \& \text { is Allowed }=\mathrm{y}}>($ luettu 13.2.2019).

KM Auli Toikkanen on valmistunut luokanopettajaksi Jyväskylän yliopistosta ja opiskelee teatteria Turun Taideakatemiassa.

KT, FM Tïna Nikkola toimii Jyväskylän yliopiston opettajankoulutuslaitoksessa yliopistonopettajana. 